\title{
INFORMATOLOGIA IN THE AREA OF PLANETARY COMMUNICATION
}

\author{
Mario Plenković \\ Sveučilište u Zagrebu, Grafički fakultet, Zagreb, Hrvatska \& Alma Mater Europaea - ECM E Univerza v Mariboru, \\ Fakulteta za elektrotehniko, računalništvo in informatiko, Inštitut za medijske komunikacije, Maribor, Slovenija
}

\begin{abstract}
The scientific and editorial programming orientation of the scientific journal INFORMATOLOGIA (1969. - 2019.) was based on the historical, present and future promotion of information and communication sciences, publishing of selected scientific and professional papers by renowned internationally recognized information and communication scientists, who have earned their scientific achievements on an ongoing basis place on the pages of the reputable magazine INFORMATOLOGIA. The editorial and programmatic orientation of the scientific journal Informatologia (1969. - 2019.) was based on, numerous scientific and professional critical editorial dilemmas, analyzing, valorizing and selecting quality scientific information and communication production for publication in the journal Informatologia. In a strategic journalistic sense, the editorial board members respected high scientific standards, peer-reviewed expert opinion, and affirmed selection based on critical awareness and ethical editorial principles in the selection of copyrighted productions for the publication of scientific and professional papers.
\end{abstract}

Keywords

Informatologia, communication science, scientific publishing

Numerous scholars understand information science (the triad: information, communication and the medium) as the basic social communication process. It follows that the overall structure of social order is related to the transmission of intelligible and usable information. Information science, as a science, thus evolved in the stages of descriptions, lists, regulations, dissemination, and the informative and communicative regulation of sent messages. The theory and practice of information and communication has become increasingly aware of, and has been given, the scientific dignity of information generation, making human communication more successfully regulated, with a view to developing human and social communities, at all levels of the global, regional, national and local communicative communities.

It is evident from the history of communication as well as other sciences that every progressive scientific man's step has always been long prepared and conditioned by the degree of development of new information and communication technology (ICT). Without timely and valid information and adequate communication, every progressive step (scientific, information, communication, media,...) of every person in a new inclusive information society is almost impossible. Historically, kinetic or spacial communication has enabled a person to emerge from the "world of zoos" and enabled that same person to work with another person (the communication community). Without information and communication, every work process of a person is almost impossible, because before the beginning of work, during and after work, the person (s) must communicate in order to coordinate their work and communication processes as well as other life activities. As it is well known, man has lived and worked in kinetic communication for over a million years. At the beginning of the development of kinetic communication, which developed man's ideomotor (kinetic language), the 
emergence of verbal communication emerged as a (non)dominant human expression. In such a communicative process, sound was in the function of movement and image, and was used to detail human kinetic expression. Specifically, the kinetic code becomes too narrow to store human information and communication experiences. The sonic "subcode" made it possible to expand the overall communication capacity of the "kinetic code", which became communicatively unsuitable for the maintenance and functioning of everyday communication, in the new conditions of accumulated human experience. The kinetically sound communication code replaces the effective "verbal communication" code which led to the development of temporal communication. Through the development of temporal communication, humanity, in its history, not only remained on verbal communication, but somewhere between 5,000 and 3,000 BC, it advanced literary communication, which paved the way for the discovery of new extra-psychic information storage systems. Literary communication destroys the mythic communicative consciousness (myth) and communicatively develops a new philosophy of science and art as a new superior view of the life and consciousness of communication. The strong development of ancient civilization, following the Renaissance, led to a new printing communication revolution (J. Gutemberg, 1450). Print science communication democratizes the human mind, schools are being opened up massively as information dissemination institutions (library information science). Humanity did not stop at this stage of communication development, but new inventions (from basic tools to new ICT) in the 20th century led to a new communication revolution (film, radio, television, electronic communication, computer, graphic communication, mobile and digital technology), multimedia communications, audio and video components), which (in 1969) led to the recognition of a separate science of communication (communication science), which, indeed, today becomes one of the dominant general science of communication.

Then a new field of information science (the theory and practice of information and communication) is scientifically structured and realized, which is based on the science of communication (communication science) as a general theory of communicative activity. In such a newly created scientific environment, the scientific journal INFORMATOLOGIA YUGOSLAVICA (1969-1990) appeared in 1969, under the wise conductorship of the bard and classic of information and communication sciences prof. Božo
Težak (1969.-1980.). After a decade of life and work, the journal was appointed in 1980 to a new editor-inchief of the scientific journal INYU (Informatologia Yugoslavica), then Assist. prof. Mario Plenković, Doctor of Information and Organizational Sciences, with the operational technical and expert assistance of the valuable Mrs. Branka Škvorc Podunavac (1980. - 1990.). After the independence of the Republic of Croatia, the scientific journal Informatologia Yugoslavica continued its successful programmatic and editorial orientation, under the name of INFORMATOLOGIA under the guidance of the editor-in-chief, prof. Ph.D. Mario Plenkovic (1990 2019). The scientific and editorial programming orientation of the scientific journal INFORMATOLOGIA (1969. - 2019.) was based on the historical, present and future promotion of information and communication sciences, publishing of selected scientific and professional papers by renowned internationally recognized information and communication scientists, who have earned their scientific achievements on an ongoing basis place on the pages of the reputable magazine INFORMATOLOGIA. The editorial and programmatic orientation of the scientific journal Informatologia (1969. - 2019.) was based on, numerous scientific and professional critical editorial dilemmas, analyzing, valorizing and selecting quality scientific information and communication production for publication in the journal Informatologia. In a strategic journalistic sense, the editorial board members respected high scientific standards, peer-reviewed expert opinion, and affirmed selection based on critical awareness and ethical editorial principles in the selection of copyrighted productions for the publication of scientific and professional papers. For the past five decades, the editorial board has, on the basis of the total author's production offered, considered a fair and highly responsible editorial balance, respecting the communicative principles that, at all times, public scientific information relation of one mind to another is based on the total scientific, teaching and existential authorial perspectives. After the emergence of the scientific journal INFORMATOLOGIA (1969), the key relationship between education and science without which the problems of the social and technological sphere at all levels of global, regional, national and local educational and scientific communication cannot be solved. Founder of the scientific journal Informatologia Yugoslavica, distinguished scientist prof.dr.sc. Božo Težak, outlined the editorial concept of the journal and put in the focus of editorial policy the promotion of scientific developments, thus affirming and promoting the new profile of information and communication scientists. Based on his considerations, the editorial section 
"INFORMATION AND COMMUNICATION SCIENCES: SCIENTISTS AND SCIENTIFIC INSTITUTIONS" and "NEWS" was introduced.

In this way, the information and communication profession is popularized and transformed into an interactive dialectical scientific communication forum between education, science, society and technology. On the pages of the scientific journal Informatologia, a new complementary editorial scientific conception of the journal (1980 - 2019) was developed, under the guidance of the editor-in-chief, Prof.Dr.sc. Mario Plenkovic, who gave broader and greater importance to the scientific journal in interactional communicative social relationships (information, communication, emotion, human will, morality, media, information systems, ICT, 3D, media design, multimedia, visual communications, social networks and digital communication ) which stemmed from Augustine's famous credo ut intelligam thesis (I believe to know). The editorial board of Informatologiae has opted for an interactive dialectical relationship between education, science, society and technology (ICT), in which everything in society is determined not by technology (ICT) but by other scientific and educational factors, especially the factor of information and communication will, which form a new value communicative awareness of synthetic observation of informatology and communication science.

New synthetic information science on the theory and practice of information and communication (informatology) and communication science, on the pages of Informatologia, are opening a new historical period of management and leadership (information and communication management). Information and communication science defines and determines the new modern digitized convergent media interaction, communicative and digitized inclusive information society (Social Network, Facebook, Twitter, YouTube, Flickr, Bluetooth, bloggers, web communication, mobile applications, chat services, histogram, iPhone, instant messaging (IM), new IM applications, WhatsApp, Facebook Messenger, Big Data, Metricom,...). Creative informatology and communication science require new information and communication skills and media skills for virtual communication. The programmatic orientation of the scientific journal Informatologia must be viewed from the aspect of managing, conducting and evaluating media, corporate, promotional, economic, political, geostrategic, religious, cultural, educational and other information, communication and media events. The editorial board of the scientific journal Informatologia has opted to promote the information and communication thought (scientific word) of all relevant information and communication scientists on the pages of the journal. In journalistic terms, the editorial board wants information and communication science to "rise to the sky" (scientific production of all information and communication scientists), but, without the information and communication content sense, the scientific word "will never reach the sky".

The new information, communication and media image of the world is in the interactive dialectical relationship between education, science, society and technology. The image of the world on the pages of Informatologiae becomes "so close" and at the same time "so far away". In its 50th successful editorial years of existence and activity, Informatologia actively promotes the information and communication syntagm: "Information + communication (relation) = action". The information-communication relationship forms the basis for new information editorial insights, ideas, motives and scientific words as symbols of thought and drivers of information and communication action on the pages of our INFORMATOLOGIA. What is the editorial concept of the scientific journal INFORMATOLOGIA today, or who are the information and communication scientists who have dominated their scientific and professional articles over the past 50 years on the pages of the scientific journal?

The Author Index best tells who the distinguished national and international information and communication scientists are and how much they, as individuals, contribute to the development of the scientific corpus of information and communication sciences at all levels of global, regional, national and local scientific communication. Informatologia regularly publishes scientific and professional papers in the field of information and communication sciences, related to the theory and practice of information and communication, information technology (IT), education, communication science, journalism, public relations, media and visual communication, organization and translatology, as well as papers in related scientific fields in the form of separates from the social sciences and humanities (Separati Speciale). The journal is financially supported by the Ministry of Science and Education of the Republic of Croatia. Informatologia is referenced in numerous primary and secondary databases. Up to now, 52 volumes of magazines (208 suppositories) and 23 Separate Specials have been regularly published in a range of 24,960 pages of A4 printed text. From the editorial point of 
view, to the daily-operating editorial and editorial scientific and journalistic orientation of the journal, we can say that these are highly achieved progressive production results (1969 - 2019). The editorial scientific and programmatic orientation of INFORMATOLOGIA has become recognizable at all levels of global, regional, national and local scientific and professional information, communication and media communications (EASA, ORBICOM, ICA, FIJET and IFCA). All of the above indicates that the editorial and programmatic orientation of the scientific journal INFORMATOLOGIA (1969-2019) has maintained a high scientific, ethical, peer-reviewed editorial and publicity standard. We would like to express our gratitude, in this commemorative festive introduction, to all past and present members of the Editorial Board and Editorial Members, authors, reviewers and contributors, as well as the author of the cover (Josip Škvorac), lecturer Prof.Dr.sc. Slobodan Elezović, proofreader Asst. Darija Mustić. We owe great thanks to the first Editor-in-Chief, deceased
Prof. Dr.Sc. Božo Težak (1969. - 1980-) and valuable operative and technical editor Mrs. Branka Škvorc Podunavac, as well as all those who have contributed to the quality of editing, development and sustainability of the scientific journal INFORMATOLOGIA (1969. - 2019.) in the last five decades. Special thanks go to the publisher of the scientific journal: CROATIAN COMMUNICOLOGICAL SOCIETY (1993 - 2019).

The scientific journal INFORMATOLOGIA was founded in 1969. in the horizon of the development of a new future for planetary communication, in the year when man stepped on the moon, and in the year when communication science was recognized as an independent scientific discipline (Montreal, 1969),... (...)..., however, the future of INFORMATOLOGIA is scientifically and editorially owned by information science and communication science in the newly developed inclusive information global society.

\title{
INFORMATOLOGIA U OBZORJU PLANETARNE KOMUNIKACIJE
}

\author{
Mario Plenković \\ University of Zagreb, Faculty of Graphic Arts, Zagreb, Croatia \& Alma Mater Europaea - ECM \& University of \\ Maribor, Faculty of Electrical Engineering and Computer Science, Institute of Media Communications, Maribor, Slovenia
}

\section{Sažetak}

Znanstvena i urednička programska orijentacija znanstvenog časopisa INFORMATOLOGIA (1969. - 2019.) temeljila se na povijesnoj, sadašnjoj i budućoj promociji informacijskih i komunikacijskih znanosti, objavljivanju odabranih znanstvenih i stručnih radova poznatih međunarodno priznatih znanstvenika iz područja informacijskih i komunikacijskih znanosti, koji su kontinuirano objavljivali svoja znanstvena dostignuća na stranicama uglednog časopisa INFORMATOLOGIA. Redakcijsko-programska orijentacija znanstvenog časopisa Informatologia (1969. - 2019.) temeljila se na brojnim znanstvenim i stručnim kritičkim uredničkim dilemama, analiziranju, vrednovanju i odabiru kvalitetne znanstvene informacije i komunikacijske produkcije za objavljivanje $\mathrm{u}$ časopisu Informatologia. U strateškom publicističkom smislu članovi uredništva poštovali su visoke znanstvene standarde, recenzirali kroz stručno mišljenje i potvrdili izbor utemeljen na kritičkoj svijesti i etičkim uređivačkim principima.

\section{Ključne riječi}

Informatologija, komunikacijska znanost, znanstveno objavljivanje 